\title{
Quality of Life and Physical Activity among University Students
}

\author{
Güner Çiçek \\ Faculty of Sport Sciences, Hitit University, Turkey
}

Copyright $\bigcirc 2018$ by authors, all rights reserved. Authors agree that this article remains permanently open access under the terms of the Creative Commons Attribution License 4.0 International License

\begin{abstract}
This study was to investigate the physical activity (PA) and quality of life (QoL) of sports department students (SDS) and other department students (ODS) attending university. A total of 300 university students participated in this study. 150 SDS (age; $20.67 \pm 1.65$ years) including 89 males and 61 females and 150 ODS (age; $19.45 \pm 1.22$ years) 56 males and 94 females. To determine the physical activity levels, International Physical Activity Questionnaire (IPAQ) short and Quality of Life questionnaire-short form (WHOQOL-BREF) were applied. The weekly physical activity scores of SDS and ODS were $5386.24 \pm 3528.47$ MET-min/week and 1616.85 \pm 1249.12 MET-min/week respectively and statistically difference was found $(\mathrm{p}<0.001)$. QoL levels and physical, psychological, social relations and environmental parameters of SDS were found to be higher than ODS and statistically significant $(p<0.001)$. In comparison with the genders, the total average PA score of men was found as $4938.86 \pm 3919.33$ MET-minute/week while that of women was found as 2592.44 \pm 2276.82 MET-minute/week. In the QoL parameters, only the social relations of men were higher than women, and a statistically significant difference was found $(\mathrm{p}<0.001)$. In university students, it was found that as the PA scores increased, QoL levels also increased and there was a positive relationship between them. Students should be encouraged to do sport in their spare time to improve their QoL levels.
\end{abstract}

Keywords Quality of Life, Physical Activity Level, University Students

\section{Introduction}

Physical activity (PA) improves general health and quality of life [1]. PA associated with several aspects of quality of life (QoL) [2] and PA is found to be an important means of increasing QoL [3] This relationship has been consistently reported in earlier studies $[4,5]$. Which showed that physically active individuals assessed some of their quality of life domains higher than their physically non-active counterparts $[6,7,8]$.

In addition to PA is a good way for the person to improve his physical, psychological and emotional health [9] and positively influences the personal perception of QoL and well- being [10, 11]. QoL is a multidimensional construct, including psychological, physical, social and environmental domains [12]. There are four basic environments in which individuals can be physically active. These environments are workplace, transportation (walking, cycling etc.), households and leisure time activities (sports and recreational activities) [13]. Previous studies have reported positive relationships between PA and various QoL indicators [14, 15]. Some of published studies have investigated the relationship between PA and satisfaction with life among healthy, young adults and college students $[16,17,18]$. And they have found health education programs designed to promote regular PA and increase physical self-esteem may be effective in improving QoL in young adults [18]. In addition to high-frequency activity of mild intensity that produces high kcal utilization and is performed to improve health and fitness has the strongest influence on QoL reports [16].

The aim of this study was to investigate relationship between PA level and QoL of sports department students and the other department students and to search whether there is any difference between the PA level and QoL of these two departments' students.

\section{Material and Methods}

\subsection{Study Group}

A questionnaire has been applied to 150 sports department students (who students studying in physical education) (SDS) including 89 males and 61 females (ages: $20.67 \pm 1.65$ years, height: $174.10 \pm 7.12 \mathrm{~cm}$, body mass index: $23.02 \pm 3.82 \mathrm{~kg} / \mathrm{m}^{2}$ ) and 150 the other department students (ODS) including 56 males and 94 females (ages: 
$19.45 \pm 1.22$ years, height: $168.52 \pm 8.53 \mathrm{~cm}$, body mass index: $21.58 \pm 3.04 \mathrm{~kg} / \mathrm{m}^{2}$ ) studying at the Corum Hitit University, in order to determine their PA level and QoL.

\subsection{Data Collecting Tools}

The questionnaire has been applied by way of face-to-face interview method. General Information form has been prepared by the researcher so as to be able to obtain information about the occupations, ages, genders, body weights heights and body mass index of the participants.

\subsubsection{Physical Activity (PA)}

Physical activity (PA) level was determined using the Turkish validated short-form version of the IPAQ. The validity and the credibility studies of the questionnaire in Turkey were conducted by Ozturk [19]. In our study, a self-administered short form with 7 questions covering the last 1 week in the assessment of PAL was used. The results allowed energy expenditure to be estimated in metabolic equivalent minutes per week (MET-min/week). For that, an average MET score is attributed for each type of activity: 3.3 METs for walking, 4.0 METs for moderate activity and 8.0 for vigorous activity. PA level have been classified into three groups as physically inactive ( $<600 \mathrm{MET}-\mathrm{min} / \mathrm{week})$, low-PA level (low active) (600-3000 MET- min/week) and adequate PA level (useful in terms of health) ( $>3000$ MET$\mathrm{min} /$ week).

\subsubsection{Quality of Life (QoL)}

Quality of life (QoL) was assessed using the validated. Turkish version of the the WHOQOL-BREF was translated and adapted into Turkish by Fidaner et al. [20]. The brief version of the WHOQOL-BREF contains 26 items, with each item representing one facet. The four main domains have the following facets: (1) physical health domain: to be free of any pain, sleep and rest, mobility, having energy, mobility, activities of daily living, to be free of dependence on medication and treatments, and work capacity; (2) psychological health domain: happiness and enjoyment of life, to be able to concentrate, feeling positive about yourself, bodily image and appearance, to be free of negative feelings, and religion/spirituality/personal beliefs; (3) social relationships: sexual activity, personal relationships, and social support; (4) environment: feeling physical safety and security, home environment, financial resources, to be able to adequate health care, changes of getting new information and knowledge, participation in recreation/leisure, adequate transport and physical environment. All items on the WHOQOL-BREF are scored on a 5-point Likert Scale with total scores ranging from 25 to 125 points and higher scores representing a greater quality of life [20].

\subsection{Statistical Analysis}

In this study, SPSS 20 statistical program was used for the data measured. The Kolmogorov-Smirnow test was used when determining whether the variables had normal distributions or not, and the Mann Whitney-U test was used to compare the difference in physical activity and WHOQOL levels between the two departments and the genders since they were not normally distributed. The Chi-square test was used to determine physical activity scores among departments and genders, and the Spearman correlation test was used to determine the relationship between the physical activity and WHQOOL. 


\section{Results}

Table 1. Comparison of physical activity and WHOQOL levels among departments.

\begin{tabular}{|c|c|c|c|c|c|c|}
\hline Physical Activity Level & Departments & $\mathbf{n}$ & $\begin{array}{c}\text { Median } \\
(\min , \max )\end{array}$ & Mean & SD & $\mathbf{p}$ \\
\hline \multirow{2}{*}{ Severe Activity } & Sports & 150 & $2880.0(0-14400)$ & 3068.87 & 2517.70 & \multirow{2}{*}{$0.00^{* *}$} \\
\hline & Other & 150 & $0.00(0-3840)$ & 272.53 & 582.508 & \\
\hline \multirow{2}{*}{ Moderate Activity } & Sports & 150 & $480.0(0-6000)$ & 942.40 & 1123.47 & \multirow{2}{*}{$0.00^{* *}$} \\
\hline & Other & 150 & $0.00(0-2880)$ & 221.20 & 456.34 & \\
\hline \multirow{2}{*}{ Low Activity } & Sports & 150 & $1386.0(0-8316)$ & 1844.49 & 1416.10 & \multirow{2}{*}{$0.00 * *$} \\
\hline & Other & 150 & $792.0(99-4158)$ & 1125.66 & 864.16 & \\
\hline \multirow{2}{*}{ Total Activity } & Sports & 150 & $4879.0(960-17424)$ & 5386.24 & 3528.47 & \multirow{2}{*}{$0.00^{* *}$} \\
\hline & Other & 150 & $1386.0(0-6330)$ & 1616.85 & 1249.12 & \\
\hline \multirow{2}{*}{ Sitting time } & Sports & 150 & $300.0(0-840)$ & 316.00 & 149.52 & \multirow{2}{*}{$0.00^{* *}$} \\
\hline & Other & 150 & $420.0(60-960)$ & 418.40 & 188.58 & \\
\hline \multicolumn{7}{|l|}{ WHQOOL level } \\
\hline \multirow{2}{*}{$\begin{array}{l}\text { Physical } \\
\text { Health }\end{array}$} & Sports & 150 & $27.0(13.0-35.0)$ & 26.98 & 4.26 & \multirow{2}{*}{$0.00 * *$} \\
\hline & Other & 150 & $25.50(13.0-22.0)$ & 25.07 & 4.27 & \\
\hline \multirow{2}{*}{$\begin{array}{l}\text { Psychological } \\
\text { health }\end{array}$} & Sports & 150 & $23.0(9.0-30.0)$ & 22.92 & 4.00 & \multirow{2}{*}{$0.006^{* *}$} \\
\hline & Other & 150 & $22.0(13.0-66.0)$ & 22.14 & 5.14 & \\
\hline \multirow{2}{*}{$\begin{array}{c}\text { Social } \\
\text { relationships }\end{array}$} & Sports & 150 & $23.57(9.0-30.0)$ & 22.92 & 3.99 & \multirow{2}{*}{$0.00^{* *}$} \\
\hline & Other & 150 & $11.0(5.0-15.0)$ & 10.77 & 2.31 & \\
\hline \multirow{2}{*}{ Environment } & Sports & 150 & $29.0(9.0-40.0)$ & 28.74 & 4.72 & \multirow{2}{*}{$0.034^{*}$} \\
\hline & Other & 150 & $28.0(16.0-55.0)$ & 27.90 & 4.93 & \\
\hline
\end{tabular}

$\mathrm{P}<0.001^{* *}$ and $\mathrm{p}<0.05^{*}$ Mann Whitney - U test

In Table 1, when we look at the levels of physical activity among the departments, there is a significant difference among high, medium, low, total activities and sitting times $(\mathrm{p}<0.001)$. It was found that high, medium, low and total activity scores of the students studying in the sports department were higher than those of the students studying in the other department. The sitting times were found higher in the students studying in other departments. In the WHOQOL parameters, there is a significant difference at a level of $\mathrm{p}<0.001$ in physical health, psychological and social relations, and $\mathrm{p}<0.05$ in the environmental parameter. Physical, psychological, social relations and environmental parameters of the students studying in sports department were found higher. 
Table 2. Comparison of gender-specific physical activity and WHOQOL levels

\begin{tabular}{|c|c|c|c|c|c|c|}
\hline Physical Activity Level & Gender & $\mathbf{n}$ & $\begin{array}{c}\text { Median } \\
(\min , \max )\end{array}$ & Mean & SD & $\mathbf{p}$ \\
\hline \multirow{2}{*}{ Severe Activity } & Male & 145 & $1440.0(0-14400)$ & 2500.07 & 2743.46 & \multirow{2}{*}{$0.00 * *$} \\
\hline & Female & 155 & $0.00(0-7680)$ & 894.84 & 1406.46 & \\
\hline \multirow{2}{*}{ Moderate Activity } & Male & 145 & $480.0(0-6000)$ & 741.79 & 1078.99 & \multirow{2}{*}{$0.001 * *$} \\
\hline & Female & 155 & $120.0(0-4800)$ & 432.13 & 735.34 & \\
\hline \multirow{2}{*}{ Low Activity } & Male & 145 & $1386.0(66-8316)$ & 1702.41 & 1450.68 & \multirow{2}{*}{0.044} \\
\hline & Female & 155 & $1188.0(0-5544)$ & 1281.77 & 927.65 & \\
\hline \multirow{2}{*}{ Total Activity } & Male & 145 & $3900.0(0-17424)$ & 4938.86 & 3919.33 & \multirow{2}{*}{$0.00 * *$} \\
\hline & Female & 155 & $1670.0(264-15252)$ & 2592.44 & 2276.82 & \\
\hline \multirow{2}{*}{ Sitting time } & Male & 145 & $300.0(60-960)$ & 368.28 & 178.41 & \multirow{2}{*}{0.908} \\
\hline & Female & 155 & $300.0(0-900)$ & 366.19 & 177.14 & \\
\hline \multicolumn{7}{|l|}{ WHQOOL level } \\
\hline \multirow{2}{*}{$\begin{array}{l}\text { Physical } \\
\text { Health }\end{array}$} & Male & 145 & $27.0(13.0-35.0)$ & 26.26 & 4.54 & \multirow{2}{*}{0.281} \\
\hline & Female & 155 & $26.0(13.0-35.0)$ & 25.80 & 4.20 & \\
\hline \multirow{2}{*}{$\begin{array}{l}\text { Psychological } \\
\text { health }\end{array}$} & Male & 145 & $23.0(13.0-30.0)$ & 22.66 & 3.81 & \multirow{2}{*}{0.313} \\
\hline & Female & 155 & $23.0(9.0-66.0)$ & 22.40 & 5.25 & \\
\hline \multirow{2}{*}{$\begin{array}{c}\text { Social } \\
\text { relationships }\end{array}$} & Male & 145 & $20.0(5.0-30.0)$ & 18.28 & 7.08 & \multirow{2}{*}{$0.001 * *$} \\
\hline & Female & 155 & $13.0(6.0-29.0)$ & 15.50 & 6.46 & \\
\hline \multirow{2}{*}{ Environment } & Male & 145 & $28.0(17.0-55.0)$ & 28.60 & 5.11 & \multirow{2}{*}{0.521} \\
\hline & Female & 155 & $28.0(9.0-40.0)$ & 28.06 & 4.58 & \\
\hline
\end{tabular}

$\mathrm{P}<0.05^{*}$ and $\mathrm{P}<0.001 * *$ Mann Whitney - U test

When we look at the gender-specific physical activity levels in Table 2, there is a significant difference among high, medium, total activities $(p<0.001)$ and in the low activity level at a level of $p<0.05$. There is no significant difference in sitting time variable. Also, in WHQOL parameters, there was no significant difference found between genders in physical health, psychological and environmental variables. The social relations of men are higher than those of women, and there is a statistically significant difference $(\mathrm{p}<0.001)$.

Table 3. Comparison of physical activity scores according to department and gender

\begin{tabular}{|c|c|c|c|c|c|c|c|c|c|c|}
\hline \multicolumn{11}{|c|}{ Physical Activity Level } \\
\hline & & \multicolumn{2}{|c|}{ Inactive } & \multicolumn{2}{|c|}{ Low active } & \multicolumn{2}{|c|}{ Adequate } & \multicolumn{2}{|c|}{ Total } & \multirow[b]{2}{*}{$\mathrm{p}$} \\
\hline & & $\mathrm{n}$ & $\%$ & $\mathrm{n}$ & $\%$ & $\mathrm{n}$ & $\%$ & $\mathrm{n}$ & $\%$ & \\
\hline \multirow{3}{*}{ Department } & Sports & 9 & 6.0 & 26 & 17.3 & 115 & 76.7 & 150 & 100.0 & \multirow{3}{*}{$0.00 * *$} \\
\hline & Other & 26 & 17.3 & 105 & 70.0 & 19 & 12.7 & 150 & 100.0 & \\
\hline & Total & 35 & 11.7 & 131 & 43.7 & 134 & 44.7 & 300 & 100.0 & \\
\hline \multirow{3}{*}{ Gender } & Men & 12 & 8.3 & 46 & 31.7 & 87 & 60.0 & 145 & 100.0 & \multirow{3}{*}{$0.00 * *$} \\
\hline & Female & 23 & 14.8 & 85 & 54.8 & 47 & 30.3 & 155 & 100.0 & \\
\hline & Total & 35 & 11.7 & 131 & 43.7 & 134 & 44.7 & 300 & 100.0 & \\
\hline
\end{tabular}

$\mathrm{P}<0.001 * *$ Chi-square test

When we compare the physical activity scores according to departments in Table 3 , there is a statistically significant difference between the two groups $(\mathrm{p}<0.001)$. The physical activity scores of the students studying in the sports department are at a level of $76.7 \%$ being sufficient, $17.3 \%$ low, and $6.0 \%$ non-active. Of the other department, $12.7 \%$ are sufficiently active, $70.0 \%$ are low active, and $17.3 \%$ are non-active. Physical activity scores of students who study in the sports department were found higher. There is a statistically significant difference when we compared physical activity scores according to genders $(\mathrm{p}<0.001)$. Of the male students, $60.0 \%$ are at sufficient level, $31.7 \%$ are at low level, and $8.3 \%$ are at non-active level. Of the women $30.3 \%$ are at sufficient level, $54.8 \%$ are at low level, and $14.8 \%$ are at non-active level. Physical activity scores of men were found to be higher than those of women. 
Table 4. Relationship between physical activity and WHOQOL

\begin{tabular}{|c|c|c|c|c|c|}
\hline & & $\begin{array}{c}\text { Physical } \\
\text { Health }\end{array}$ & $\begin{array}{l}\text { Psychological } \\
\text { Health }\end{array}$ & Social Relationships & Environment \\
\hline \multirow{3}{*}{ Severe Activity } & $\begin{array}{l}\text { Correlation } \\
\text { Coefficient }\end{array}$ &, $201 * *$ &, $141 *$ &, $638 * *$ &, $123 *$ \\
\hline & $\mathrm{P}$ value &, 000 & 015 &, 000 & ,033 \\
\hline & $\mathrm{N}$ & 300 & 300 & 300 & 300 \\
\hline \multirow{3}{*}{ Moderate Activity } & $\begin{array}{l}\text { Correlation } \\
\text { Coefficient } \\
\end{array}$ &, 031 & 033 &, $404 * *$ & ,013 \\
\hline & $\mathrm{P}$ value & ,594 &, 574 &, 000 & ,828 \\
\hline & $\mathrm{N}$ & 300 & 300 & 300 & 300 \\
\hline \multirow{3}{*}{ Low Activity } & $\begin{array}{l}\text { Correlation } \\
\text { Coefficient }\end{array}$ &, $130^{*}$ & ,102 &, $293 * *$ &, 044 \\
\hline & $P$ value &, 025 & 079 &, 000 & ,445 \\
\hline & $\mathrm{N}$ & 300 & 300 & 300 & 300 \\
\hline \multirow{3}{*}{ Total Activity } & $\begin{array}{l}\text { Correlation } \\
\text { Coefficient }\end{array}$ &, $196 * *$ &, $134^{*}$ &, $632 * *$ & ,093 \\
\hline & $\mathrm{P}$ value & ,001 & ,020 &, 000 & ,107 \\
\hline & $\mathrm{N}$ & 300 & 300 & 300 & 300 \\
\hline \multirow{3}{*}{ Sitting Time } & $\begin{array}{l}\text { Correlation } \\
\text { Coefficient }\end{array}$ &,- 075 & ,-076 &,$- 237 * *$ &,- 007 \\
\hline & $P$ value & ,193 & ,189 &, 000 & ,907 \\
\hline & $\mathrm{N}$ & 300 & 300 & 300 & 300 \\
\hline
\end{tabular}

$\mathrm{P}<0.005^{*}$ and $\mathrm{p}<0.001^{* *}$ Spearman correlation test

When we look at the correlation relation between physical activity and WHOQOL in Table 4, there is a significant relationship between severity activity and total activity with physical health, psychological, social relations and environment $(\mathrm{p}<0.005$ and $\mathrm{p}<0.001)$. It was determined that low activity had a significant relation with physical and social relation, and also, moderate activity and sitting time had a significant difference in the social relation $(\mathrm{p}<0.005$ and $\mathrm{p}<0.001)$.

\section{Discussion}

Physical activity and exercise help people to have better mental health and physical, improve the quality of life, which enables them to live longer [21]. However, PA domains have a positive impact on QoL remain largely unknown, some of studies [22, 23] have investigated the association between specific domains of PA and QoL [8]. This study was conducted with the aim of comparing the physical activity and quality of life of students studying at the faculty of sports sciences and other faculties and determining whether the physical activity had a positive effect on the quality of life.

When we compared the PA levels of the sections in our study, the PA levels of SDS were found to be significantly higher $(\mathrm{p}<0.001)$. The mean total activity score of the SDS was $5386.24 \pm 3528.47 \mathrm{MET}$-minute/week while that of ODS was found to be $1616.85 \pm 1249.12$ MET-minute/week. In the sitting times, while SDS was $316.00 \pm 149.52$ in average, ODS was found to be $418.40 \pm$
188.58 and SDS was found to be lower than ODS. In addition, high, moderate and low PA levels of SDS were statistically higher than ODS $(\mathrm{p}<0.001)$. Taşmektebligil et al. [21] stated that they found in a similar study they have done that the sports department students' total physical activity score (5681.32 \pm 238.237 MET-minute/week) was higher than that of students studying in other departments (1612.46 \pm 80.727 MET-minute/week), and that sitting times was lower.

When we look at QoL levels, the physical, psychological, social relations and environmental parameters of SDS are higher than those of ODS and are statistically significant ( $p$ $<0.001)$. It was determined that the students in the sports department were more active than the other departments' students and that they improved their QoL parameters positively. It can be said that the high levels of PA in SDS are because of the lifestyles, lessons taken, active participation in any sports branch of the students studying in this department. Kim et al. (2010) showed that PA related to sport and recreation, rather than to work, was positively related to QoL [24]. The results of our study confirm that as the level of physical activity increases, the QoL levels increase and that there is a positive relationship between them, as noted in previous studies [14, 15].

When we compare the physical activity scores according to departments in Table 3, there is a statistically significant difference between the two groups $(\mathrm{p}<0.001)$. PA scores of SDS are at a level of $76.7 \%$ being adequately $17.3 \%$ low, and $6.0 \%$ inactive. Of ODS, $12.7 \%$ are adequate active, $70.0 \%$ are low active, and $17.3 \%$ are inactive. The PA scores of the SDS were found to be higher. There is a 
statistically significant difference when we compared physical activity scores according to genders $(\mathrm{p}<0.001)$. Of the male students, $60.0 \%$ are at adequately level, $31.7 \%$ are at low level, and $8.3 \%$ are at inactive level. Of the women $30.3 \%$ are at adequate level, $54.8 \%$ are at low level, and $14.8 \%$ are at inactive level. Physical activity scores of men were found to be higher than those of women. In the study of Vural and his friends [25] done for the PALs of White collar workers, they have revealed that 29.1 percent of females are inactive, 51.7 percent are low active and 19.2 are adequately active, and 20.6 percent of males are inactive, 45.4 percent are low active and 34.0 are adequately active. Previous studies showed that young males are more active than young females in relation to the differences dependent on gender [26, 27].

In a comparison of PA and QoL levels with the genders, the total average PA score of men was found as $4938.86 \pm$ 3919.33 MET-minute/week while that of women was found as $2592.44 \pm 2276.82$ MET-minute/week. Total and moderate PA levels of men were statistically higher than those of women $(p<0.001)$. In another similar research, the total physical activity score of female university students was found to be $1812.30 \pm 1569.40$ MET-minute/week while that of males was 2237.74 \pm 1589.45 MET-minute/week [28]. In a physical activity survey applied to the adolescents and young adults in Poland, males were found to have higher level of physical activity than females [29]. Previous studies and our results show similar; the PA level of men is higher than that of women. [21].

There was no statistically significant difference in physical, psychological and environmental variables in QoL scores between genders ( $p>0.001)$. The social relations of men are higher than those of women, and there is a statistically significant difference $(p<0.001)$. Although the physical activity level of males was higher than those of females, no significant relation was found among physical, psychological and environmental QoL scores.

Evidence from clinical trials is lesser among adults cross-sectional studies show that the relationship between PA and QoL domains does not seem to be linear [11]. Fox et al. [30] reported positive effects of a 12-month program of moderate PA on psychological, physical and environmental domains among senior women; yet, there was no similar effect in the social relations domain. Vagetti et al. [11] PA is associated in different ways for women and men and also for the different QoL domains. The previous literature results are similar to the results we have found.

When we looked at the correlation relation between physical activity and QoL, it was found that there was a significant relation of high activity and total activity with physical health, psychological, social relations and environment $(\mathrm{p}<0.001)$. It was determined that low activity had a significant relation with physical and social relation, and also, moderate activity and sitting time had a significant difference with social relation $(\mathrm{p}<0.001)$. Some authors suggest that the psychological quality of life is only positively affected by moderate- and high-intensity exercises [31, 8]. PA has positive effects on psychological, [32], physical [33], and emotional [34] and well-being [11]. Most studies show a positive effect of sport activity on subjective well-being in terms of happiness and life satisfaction [35, 36, 37]. Our study results showed that they developed PA and QoL levels and that there was a positive correlation between them $[38,39]$.

\section{Conclusions}

In university students, it was found that as the PA scores increased, QoL levels also increased, and there was a positive relationship between them. This relationship varied according to the gender and PA level. It was found that the students in the sports faculty had a higher level of PA and QoL scores. Students studying at other faculties should be encouraged to do any sport during their spare time to increase their levels of physical activity.

\section{REFERENCES}

[1] FitzGerald LZ., Boland D. The Impact of Behavioral and Psychological Factors on Physical Fitness in Medical and Nursing Students. Holist Nurs Pract. 32(3):125-132. 2018.

[2] Lobo A., Santos P., Carvalho J., Mota J. Relationship between intensity of physical activity and health-related quality of life in Portuguese institutionalized elderly. Geriatr Gerontol Int. 8(4):284-90, 2008.

[3] Bize R., Johnson, JA., Plotnikoff RC. Physical activity level and health-related quality of life in the general adult population: A systematic review. Preventive Medicine, 45(6), 401-415, 2007.

[4] Guedes DP, Hatmann AC, Martini FA, Borges MB, Bernardelli R Jr. Quality of life and physical activity in a sample of Brazilian older adults. J Aging Health. 24(2):212-26, 2012.

[5] Rejeski W., Mihalko S. Physical activity and quality of life in older adults. Journal of Gerontology Series A: Biological Science Medical Science, 56(2), 23-35, 2001.

[6] Puciato D., Rozpara M., Mynarski W., Łoś A., Królikowska B. Physical activity of adult residents of Katowice and selected determinants of their occupational status and socio-economic characteristics. Med Pr. 64:649-657, 2013.

[7] Chai W., Nigg C., Pagano I., Motl R., Horwath C., Dishman R. Associations of quality of life with physical activity, fruit and vegetable consumption, and physical inactivity in a free living, multi-ethnic population in Hawaii: a longitudinal study. Int J Behav Nutr Phys Act. 7:83,2010

[8] Omorou YA., Erpelding M L., Escalon H., Vuillemin A. Contribution of taking part in sport to the association between physical activity and quality of life. Quality of life research, 22(8), 2021-2029, 2013. 
[9] Galadys SFL., Frank JHL., Amyhsiu HW. Exploring the relationships of physical activity, emotional intelligence and health in Taiwan college students. National Chung Cheng University. Journal of Exercise Science \& Fitness. 7 (1):55-63.2009.

[10] McAuley E., Elavsky S., Jerome GJ., Konopack JF., Marquez DX. Physical activity-related well-being in older adults: Social cognitive influences. Psychology and Aging, 20, 295-302, 2005.

[11] Vagetti GC., Barbosa Filho VC., Moreira NB., Oliveira Vd., Mazzardo O., Campos Wd. Association between physical activity and quality of life in the elderly: a systematic review, 2000-2012. Rev Bras Psiquiatr. 36(1):76-88, 2014.

[12] Peleias M., Tempski P., Paro HB., Perotta B., Mayer FB., Enns SC., Gannam S., Pereira MAD., Silveira PS., Santos IS., Carvalho CR., Martins MA. Leisure time physical activity and quality of life in medical students: results from a multicentre study. BMJ Open Sport Exerc Med. 2;3(1), 2017.

[13] Akyol A., Bilgic B., Ersoy G. Fiziksel Aktivite, Beslenme ve Sağlıklı Yasam. Birinci Basım, Klasmat Matbaacılık, Ankara, 2008.

[14] Elavsky S., McAuley E., Motl RW., Konopack JF., Marquez DX., Hu L., et al. Physical activity enhances long term quality of life in older adults: Efficacy, esteem, and affective influences. Annals of Behavioral Medicine, 30(2), 138-145, 2009.

[15] Malebo A., Eeden C., Wissing MP. Sport participation, psychological well-being, and psychosocial development in a group of young black adults. South African Journal of Psychology. 37(1), 188-207, 2007.

[16] Lustyk MK., Widman L., Paschane AA., Olson KC. Physical activity and quality of life: Assessing the influence of activity frequency, intensity, volume, and motives. Behavioral Medicine. 30, 124-131, 2004.

[17] Maher JP., Doerksen SE., Elavsky S., Hyde AL., Pincus AL., Ram N., Conroy DE. A daily analysis of physical activity and satisfaction with life in emerging adults. Health Psychol. 32(6):647-56, 2013.

[18] Joseph RP., Royse KE., Benitez TJ., Pekmezi DW. Physical activity and quality of life among university students: exploring self-efficacy, self-esteem, and affect as potential mediators. Qual Life Res. 23(2):659-67, 2014.

[19] Ozturk M. Universitede Egitim-Ogretim Goren Ogrencilerde Uluslararasi Fiziksel Aktivite Anketinin Gecerliligi ve Guvenirligi ve Fiziksel Aktivite Duzeylerinin Belirlenmesi. Fizik Tedavi ve Rehabilitasyon Programi. Hacettepe Universitesi Saglik Bilimleri Enstitusu. Ankara, 2005.

[20] Fidaner H., Elbi H., Fidaner C., Eser SY., Eser, E. Yasam kalitesinin ölçülmesi, WHOQOL-100 ve WHOQOL-BREF. 3P. Psikiyatri Psikoloji Psikofarmakoloji Dergisi 7, 23-40, 1999

[21] Tasmektepligil MY., Agaoglu SA., Atan T., Cicek G. The contrastive study of physical activity levels of phsical education students and the other department students. International Journal of Academic Research. 5(6), 90-95, 2013.
[22] Balboa-Castillo T., Leon-Munoz LM., Graciani A., Rodriguez-Artalejo F., Guallar-Castillon P. Longitudinal association of physical activity and sedentary behaviour during leisure time with health-related quality of life in community dwelling older adults. Health and Quality of Life Outcomes, 9, 47, 2011.

[23] Vuillemin A., Boini S., Bertrais S., Tessier S., Oppert JM., Hercberg S., Guillemin F., and Briançon S., Leisure time physical activity and health-related quality of life. Preventive Medicine. 41(2), 562-569, (2005).

[24] [24] Kim I., Choi H., Davis AH. Health-related quality of life by the type of physical activity in Korea. Journal of Community Health Nursing, 27(2), 96-106, 2010.

[25] Vural O., Eler S., Atalay Guzel N. "Masa Basi Calisanlarda Fiziksel Aktivite Duzeyi ve Yasam Kalitesi Iliskisi" Spormetre Beden Egitimi ve Spor Bilimleri Dergisi. VIII (2):69-75, 2010.

[26] Silva GD., Bergamaschine R., Rosa M., Melo C., Miranda R., Bara Filho M. Evaluation of the physical activity level of undergraduation students of health/biology fields. Revista Brasileira de Medicina do Esporte. 13(1):39-42, 2007.

[27] Yahia N., Abdallah A., Achkar A., Rizk S. Physical Activity and Smoking Habits in Relation to Weight Status among Lebanese University Students. International Journal of Health Research. 3: 21-27, 2010.

[28] Savci S., Ozturk M., Arikan H., Ince D.I., Tokgozoglu L. Universite Ogrencilerinin Fiziksel Aktivite Duzeyleri. Turk Kardiyoloji Dernegi Ars; 34: 166-172, 2006.

[29] Bergier J., Kapka-Skrzypczak L., Biliński P., Paprzycki P., Wojtyła A. Physical activity of Polish adolescents and young adults according to IPAQ: a population based study. Ann Agric Environ Med. 23;19(1):109-115, 2012.

[30] Fox KR., Stathi A., McKenna J., Davis MG. Physical activity and mental well-being in older people participating in the Better Ageing Project. Eur J Appl Physiol. 100(5):591-602, 2007.

[31] Ramirez-Campillo R., Diaz D., Martinez-Salazar C., Valdés-Badilla P., Delgado-Floody P., Méndez-Rebolledo G., Cañas-Jamet R., Cristi-Montero C., García-Hermoso A., Celis-Morales C., Moran J. Effects of different doses of high-speed resistance training on physical performance and quality of life in older women: a randomized controlled trial. Clinical interventions in aging. 11, 1797, 2016.

[32] Bowling A., Banister D., Sutton S., Evans O., Windsor JA. multidimensional model of the quality of life in older age. Aging Ment Health.6:355-71, 2002.

[33] Stewart KJ., Turner KL., Bacher AC., DeRegis JR., Sung J., Tayback M., Ouyang P. Are fitness, activity, and fatness associated with health-related quality of life and mood in older persons? J Cardiopulm Rehabil. 23(2):115-21, 2003.

[34] Lee C., Russell A. Effects of physical activity on emotional well-being among older Australian women: cross-sectional and longitudinal analyses. J Psychosom Res.54:155-60, 2003.

[35] Huang H., Humphreys BR. Sports participation and happiness: evidence from US microdata. J Econ Psychol. 33:776-793, 2012. 
[36] Ruseski JE., Humphreys BR., Hallmann K., Wicker P., Breuer C. Sport participation and subjective well-being: instrumental variable results from German survey data. $\mathrm{J}$ Phys Act Health 11:396-403, 2014.

[37] Wicker P., Coates D., Breuer C. The effect of a four-week fitness program on satisfaction with health and life. International journal of public health, 60(1), 41-47, 2015.

[38] Koolhaas CM., Dhana K., Van Rooij FJA., Schoufour J. D., Hofman A., Franco, OH. Physical activity types and health-related quality of life among middle-aged and elderly adults: the Rotterdam study. The journal of nutrition, health \& aging, 22(2), 246-253, 2018.

[39] Legey S., Aquino F., Lamego MK., Paes F., Nardi AE., Neto GM., Mura G., Sancassiani F., Rocha N., Murillo-Rodriguez E., Machado S. Relationship Among Physical Activity Level, Mood and Anxiety States and Quality of Life in Physical Education Students. Clin Pract Epidemiol Ment Health. 9; 13: 82-91, 2017. 